\title{
Long-term effects of global and local changes on benthic macroinvertebrate communities in multi-stressed large rivers: the example of the Rhône River during the last 30 years
}

\author{
J.-F. Fruget ${ }^{(1), \star}$, C. Jézéquel ${ }^{(1),(2)}$, G. Archambaud ${ }^{(3)}$, J. Dessaix ${ }^{(1)}$, \\ M.-C. Roger ${ }^{(4)}$
}

Received April 30, 2015

Revised September 14, 2015

Accepted September 29, 2015

Key-words:
freshwater
macroinverte-
brates,
Rhône River,
climate change,
long-term
survey,
biological traits,
alien species

Key-words: macroinvertebrates, Rhône River, climate change, long-term biological traits alien species

\section{ABSTRACT}

The study of biological traits have enhanced the understanding of the changes in the macroinvertebrate communities of the Rhône River during the last thirty years, as well as the potential effects of hydroclimatic factors and thermal discharges on the structure and the functioning of these communities at the regional scale. If every section of the Rhône had specific features, we observed over time a trend towards a higher uniformisation of invertebrate communities, especially in the Lower section. The strong impacts of the alien species and the water warming subsequent to the 2003 heat wave have been detected in the Lower Rhône and the Middle Rhône: the communities of the Middle Rhône gradually exhibit profiles closer to those of the communities of the Lower Rhône. The Upper Rhône was less colonized by alien species but was impaired by the global warming: its communities exhibited biological profiles closer to those of communities of further-downstream zones. In this site, the thermal discharges have led to a lower diversity of the communities and a higher occurrence of eurythermic species. Hence the benthic macrofauna of the Rhône River seems to have reacted quickly and strongly to environmental changes and to the arrival of invasive species. However numerous trait adaptations being common to Mediterranean and alien species, it seems complex to evaluate the respective weight of each of these potential sources of impairment. Predicting trends in invertebrate community composition is a complex objective because of the competition between native and/or invasive species in addition to man-induced environmental variation (flow, temperature). However, if biological invasion does not occur continuously but only based on specific events (especially hydroclimatology), we can legitimately believe that this drift will continue with the arrival of new Ponto-Caspian species via the Danube-Main Canal, their usual way to western and southern Europe. The common feature of these different species is that they are essentially predators or filterers, thermophilic and euryecic, and efficient functional competitors. Finally, this study once again emphasizes the importance of long-term monitoring in the study of biological communities in the context of global warming.

(1) ARALEP, Campus LyonTech-La Doua, 66 Bld Niels Bohr, CS 52132, 69603 Villeurbanne Cedex, France

(2) Present adress: UMR 7208 BOREA - IRD 207, MNHN, 43 rue Cuvier, 75231 Paris Cedex, France

(3) IRSTEA Aix-en-Provence, 3275 Route de Cézanne, CS 40061, 13182 Aix-en-Provence Cedex 5, France

(4) IRSTEA Lyon, 5 rue de la Doua, CS 70077, 69626 Villeurbanne Cedex, France

* Corresponding author: fruget@aralep.com 


\section{RÉSUMÉ}

Effets à long-terme des changements globaux et locaux sur les communautés de macroinvertébrés benthiques des grands fleuves anthropisés : exemple du Rhône au cours des 30 dernières années

Mots-clés : $\quad$ En complément de l'aspect systématique, l'étude des traits biologiques a permis macroinvertébrés, de mieux comprendre l'évolution des peuplements de macroinvertébrés du Rhône fleuve Rhône, au cours des trente dernières années, ainsi que les effets potentiels des facteurs changement climatique, étude long-terme, traits bioécologiques, espèces invasises hydroclimatiques et thermiques sur la structure et le fonctionnement des peuplements à une échelle régionale. Si chaque tronçon du Rhône possède ses propres particularités, on observe au cours du temps une tendance vers une uniformisation des peuplements à l'échelle du fleuve. Cette tendance s'accentue à mesure qu'on descend le cours d'eau. Le peuplement du Rhône Moyen se rapproche au cours du temps du profil bioécologique du Bas Rhône. Tous deux subissent l'influence des espèces invasives et du réchauffement des eaux suite à la canicule de 2003. Le Haut Rhône subit moins fortement l'influence des espèces invasives mais subit celle du réchauffement climatique. L'effet de l'évolution thermique se traduit par une moindre variété du peuplement, tant du point de vue systématique que fonctionnel, et par une plus grande présence des espèces eurythermes. La macrofaune benthique semble ainsi réagir assez rapidement et fortement à l'évolution du milieu et à l'arrivée d'espèces invasives. Prédire l'évolution de la composition des peuplements est un objectif complexe car la compétition entre les espèces natives et/ou invasives s'ajoute aux effets des modifications environnementales liées aux activités anthropiques (débit, température). Toutefois, si le flux d'invasion n'apparaît pas continu mais fonction d'événements précis (en particulier hydroclimatiques), on peut légitimement penser que cette dérive va se poursuivre avec l'arrivée d'autres espèces ponto-caspiennes via le canal Main-Danube, corridor vers l'Europe de l'ouest et du sud. Le trait commun à ces différentes espèces est leur caractère essentiellement prédateur ou filtreur, thermophiles et euryèces, donc fonctionnellement très compétitif. Enfin, cette étude confirme l'importance des suivis à long terme des communautés biologiques, notamment dans le contexte du réchauffement climatique.

\section{INTRODUCTION}

The effects of climate change on the functioning of freshwater ecosystems have become more and more apparent over the past three decades and they are now evident (IPCC, 2013). However, long-term global-change studies are scarce, especially those on the effects of global change in large rivers. This scarcity is due to the scarcity of available long-term data sets (Daufresne and Boet, 2007).

Studies and models of the effects of global change on freshwater systems currently predict an increasing seasonality in discharge regime (i.e. more frequent floods and drought events) and decreasing mean annual discharge (Hendricks, 2001; Dai et al., 2009; Stahl et al., 2010; Giuntoli et al., 2012). These thermal and hydrological changes have important ecological consequences. Water temperature has a fundamental role in the behaviour, growth and metabolism of aquatic organisms, but also in primary production, for example (Stenseth et al., 2002). This leads to significant changes in community structure and composition, especially among macroinvertebrate communities (Daufresne et al., 2004, 2007; Durance and Ormerod, 2007, 2009; Floury et al., 2013).

For several decades many large rivers around the world have been subject to numerous global and local stressors (climate change, river channelization, dams, urban and industrial inputs, land use of their catchment, etc.) (Petts et al., 1989; Dynesius and Nilsson, 1994; Tockner et al., 2010). Despite the wide range of studies published within the field of climate change, the complex interactions of global changes with local changes in this multiple-stressor context have rarely been studied. 
The aim of this study was to fill this gap using long-time series from a large river affected by simultaneous stressors and the effects of climate change. The French Rhône River is subject to multiple disturbances (Figure 1) such as hydropower dams, warmed water discharges of nuclear power plants (NPP), urban and industrial inputs from large cities, etc. (Fruget, 1992, 2003). A survey of the thermal discharges of NPP over more than 30 years has allowed us to study the thermal changes in the Rhône River and their long-term global and local effects on the aquatic fauna and flora, especially on the benthic macroinvertebrate communities.

Previous studies on the Rhône River macroinvertebrate communities (Bady and Fruget, 2006; Daufresne et al., 2007) have shown (i) a longitudinal gradient with clear differences between the Upper and the Middle and Lower Rhône communities (i.e. upstream vs. downstream from Lyon and the Saône/Rhône confluence), (ii) a gradual shift from psychrophilic (coldwater) and rheophilic (fast-water) species towards thermophilic (warm-water) and limnophilic (slow-water) species, and (iii) no significant differences between sites located upstream vs. downstream from warmed water discharges. The main driver of theses changes appeared to be climate change. Khalanski et al. (2008) showed an increase of the river temperature by $1.6^{\circ} \mathrm{C}$ in the Upper Rhône (Bugey) and by $3.0^{\circ} \mathrm{C}$ in the Lower Rhône (Aramon) during the 1977-2004 period. These authors considered that the part due to the thermal discharges of nuclear power plants was $0.6^{\circ} \mathrm{C}$ downstream from Lyon and $1.4{ }^{\circ} \mathrm{C}$ upstream from Aramon. Three NPP and a cold-water tributary (the Isère River) are located between these two points. Previous studies have shown that the Middle and Lower Rhône macroinvertebrate communities significantly changed after the flood of november 2002, the heat wave of summer 2003, and the arrival of alien species (which occasionally became invasive). Meanwhile the Upper Rhône community became more similar to the characteristic communities of the watercourse downstream parts. These changes were gradual and mainly related to specific hydroclimatic events. The Rhône River reacted primarily to environmental conditions (flow and temperature; Figure 2). At the local scale, the effect of thermal discharges was detected through a higher proportion of eurythermic species and a homogenization of bio/ecological attributes in communities, suggesting the settlement of a macroinvertebrate assemblage more homogeneous and more tolerant to environmental changes.

So far, most studies on large rivers have primarily focused on the taxonomic structure of invertebrate assemblages. However, several recent studies examined the trait responses of communities to various types of multiple (Statzner and Bêche, 2010) or single pressures, e.g. global warming (Bonada et al., 2007), exotic species proliferation (Statzner et al., 2008), eutrophication (Lecerf et al., 2006), salinity (Piscart et al., 2005, 2006), sediment toxicity (Ducrot et al., 2005), or river dynamics loss (Statzner et al., 2005).

\section{MATERIALS AND METHODS}

\section{$>$ STUDY AREA}

An environmental long-term survey of four nuclear power plants located on the French (i.e. below the Swiss border) Rhône River over the three geographic areas (i) Bugey, (ii) SaintAlban, (iii) Cruas and Tricastin was performed since the beginning of the $80 \mathrm{~s}$. The Bugey site was located on the Upper Rhône (i.e. the portion of the river between the Swiss border and the confluence with the Saône River in Lyon), about 44 km upstream from the confluence; that of Saint-Alban on the Middle Rhône (i.e. the portion between the confluences of the Saône and Isère Rivers with the Rhône) 48 km downstream from Lyon; and those of Cruas and Tricastin on the Lower Rhône (i.e. the portion downstream from the Isère River to the delta), respectively 148 and $184 \mathrm{~km}$ downstream from Lyon (Figure 1).

Three stations were sampled at each site: one upstream $(0.5 \mathrm{~km}$ upstream at Cruas and Tricastin, $1.5 \mathrm{~km}$ at Saint-Alban but $5 \mathrm{~km}$ upstream at Bugey) called "upstream"; immediately downstream from the warmed water discharge $(0.5 \mathrm{~km}$ downstream for all sites) and called "discharge"; far downstream from the discharge after mixing had begun ( $3 \mathrm{~km}$ downstream at Cruas, 6-7 km at Bugey and Tricastin, $13 \mathrm{~km}$ at Saint-Alban) called "downstream". 


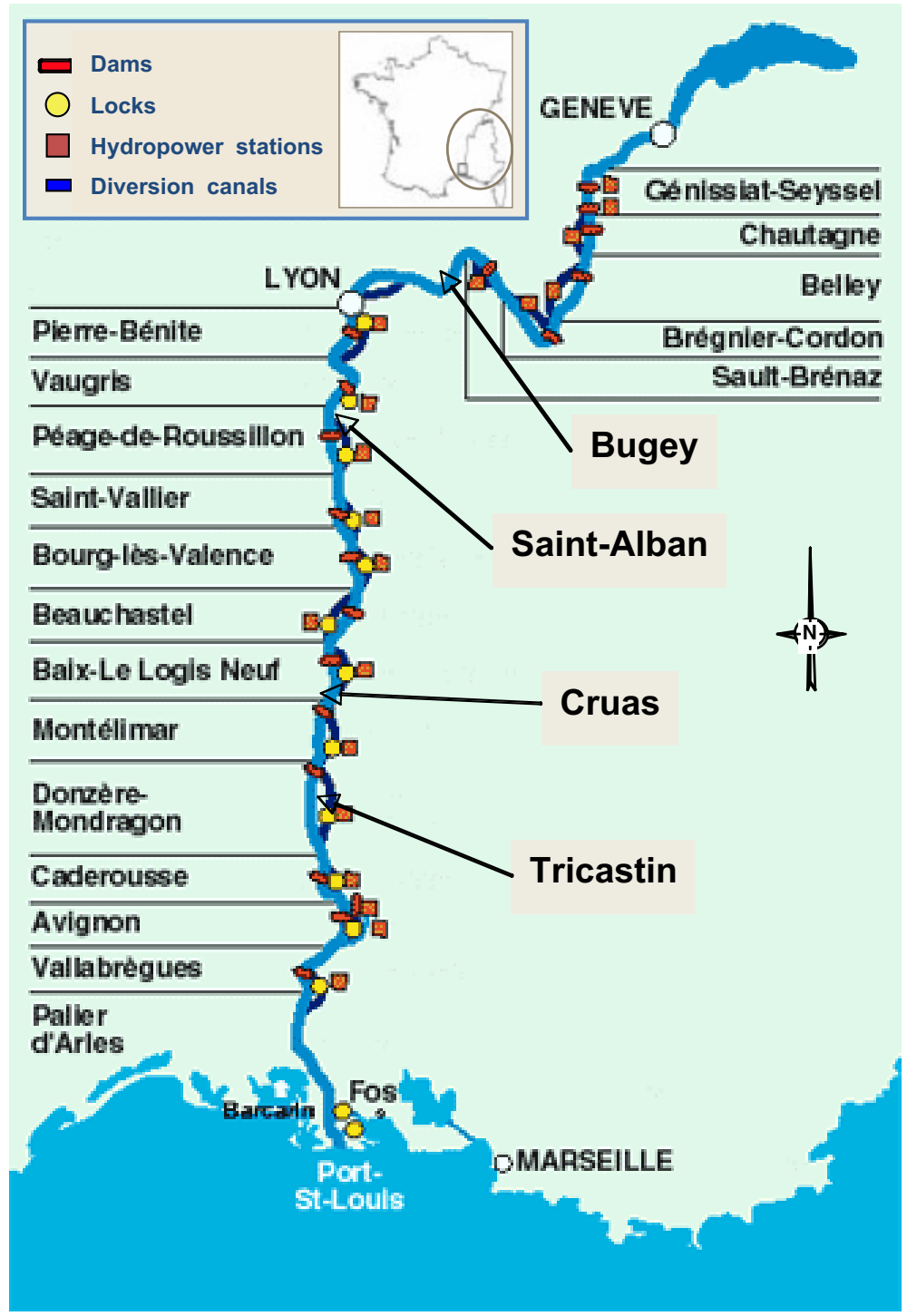

Figure 1

Location of the sampled sites and hydroelectric impoundments of the French Rhône River from Geneva to the Mediterranean sea.

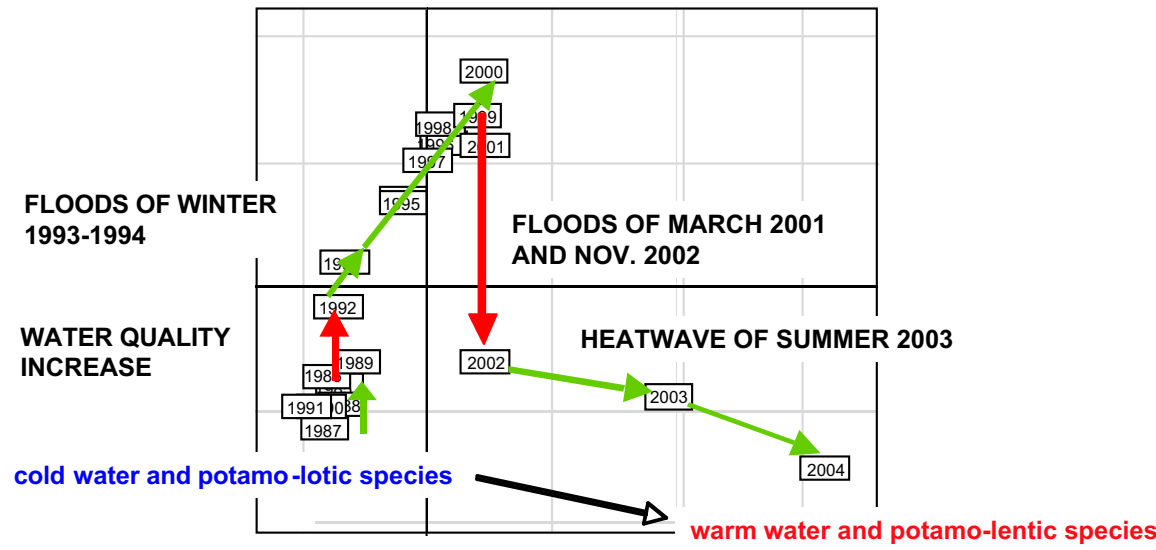

Figure 2

Synthesis of the changes in the macroinvertebrate communities of the Rhône River between 1985 and 2004 (Bady and Fruget, 2006). 


\section{> DATA COLLECTION}

The study was based on invertebrate samples collected with artificial substrates during a period of 32 years (1979-2010). The sampling design included over 1500 samples collected four times per year (i.e. one campaign per season) and per station. This method consisted in introducing an "empty" habitat into the environment for it to be be colonized by the local invertebrate fauna (see Khalaf and Tachet, 1980). The composition of the artificial substrates had to be as close as possible to the substrate types naturally present in the sampled environment. If the method did not allow a direct evaluation of macroinvertebrate densities per surface unit (the artificial substrate itself represented the "catch per unit effort", CPUE), its robustness was ensured by both the high reproducibility of the results and the high number of samples performed during the study period.

Two types of artificial substrates were used during this study: (i) CTGREF-type substrates composed of a stack of parallel cement disks with synthetic brushes (Bugey, Cruas and Tricastin) and (ii) IBGA-type substrates originally developed for the monitoring of the site of Saint-Alban, and now used for the whole monitoring network of the French large and deep rivers by Water Agencies, and composed of sisal string and stones.

These data have been archived in a database with Access software.

Parallel to biological data, water quality was evaluated each year in four seasonal sampling campaigns, in particular the parameters describing organic matter $\left(\mathrm{O}_{2}\right.$ content and $\left.\mathrm{BOD}_{5}\right)$ and nutrients (nitrogen and phosphorus).

Water temperature and Rhône discharge were also evaluated at each site. Water temperature was recorded hourly by automatic recording stations upstream from the NPP. Discharge was expressed by the hydraulicity coefficient, i.e. the ratio of the mean annual value to the mean inter-annual value. The discharge values were those of the gauging stations of Lagnieu, Ternay and Viviers, located immediately upstream from the nuclear plants of Bugey, Saint-Alban and Tricastin, respectively. Their mean inter-annual discharges were respectively 457, 1023 and $1477 \mathrm{~m}^{3} / \mathrm{s}$ over the $1920-2011$ period.

\section{$>$ DATA ANALYSIS}

\section{Time periods}

The preliminary analysis (Bady and Fruget, 2006; Daufresne et al., 2007) distinguished three time periods:

- 1979-1987: commissioning of the hydroelectric and nuclear plants;

- 1988-2002: improving water quality, high flood successions and increasing water temperature;

- 2003-2010: post-2003 heat wave with confirmation of the trend of rising temperatures and the arrival of new alien species.

\section{Taxonomy-based approach}

Taxa with only one occurrence or less than five individuals over the whole sampling design were removed from the analysis to avoid giving excessive weight to rare taxa. As a result, only 222 taxa were included in the analyses. Individuals were identified at the species level whenever it was possible. Only the genus level was identified for several invertebrate samples from Cruas and Tricastin. The Diptera were identified only at the family or subfamily level. Abundances of taxa were log-transformed $\left(x_{i}\right.$ replaced by log $\left(x_{i}+1\right)$, with $x_{i}$ being the abundance of taxon " $i$ ") so as to reduce differences in the weight of abundant vs. rare taxa.

A Correspondence analysis (CA) was applied to (i) the whole data array, and (ii) the array including the mean composition of station assemblages per year. Because the same temporal 
trends were observed in both analyses, only the second strategy will be described for better readability.

The first axis of these analyses (not shown here) opposed the Upper Rhône and Middle Rhône, while both sites of the Lower Rhône, Cruas and Tricastin, superposed in an intermediate position and described the second axis (periods 1 and 2 on the positive side and period 3 on the negative one). This indicated that these two sites had the same community basis and the same temporal variations, hence they will be grouped under the name of "Lower Rhône" for further analyses and discussions.

\section{Trait-based approach}

Based on the River Habitat Templet (Southwood, 1977; Townsend and Hildrew, 1994), the trait-based approach examines how habitat filters, including anthropogenic pressure, select combinations of morphological, physiological and behavioural traits or ecological preferences in local invertebrate communities (Tachet et al., 2000; Usseglio-Polatera et al., 2000). A fuzzy coding method based on scores (from 0 to 3 ) allocated to each taxon for the different categories of a trait (see Chevenet et al., 1994; Tachet et al., 2000) was applied to describe the biological and ecological trait profiles of the taxa.

\section{Matching taxonomy with bio-ecological information}

Co-inertia analysis (Dolédec and Chessel, 1994) was applied to examine the relationships between the spatio-temporal distribution of invertebrates in the Rhône River and their biological or ecological traits.

All analyses were performed with $R$ software using ade4 package.

\section{RESULTS}

\section{> ENVIRONMENTAL TRENDS}

Despite inter-annual variations, mean annual discharges showed a decreasing trend along the study period (Figure 3). The regression coefficients $R^{2}$ are respectively 0.155 for Bugey, 0.085 for Saint-Alban and 0.129 for Tricastin.

An inverse trend is noted for temperature (Figure 3). The regression coefficients $R^{2}$ are respectively for each sector $0.281,0.035$ and 0.461 . However, it appears lower in Saint-Alban, partly due to the post-2004 years $\left(R^{2}=0.093\right.$ over the period $\left.1985-2004\right)$.

These low linear regressions give rather trends than certainties. However, the number of dots used remains low; these are derived from average values, resulting in a smoothing of the data.

\section{Taxonomic approach}

The eigenvalues of the global CA (Figure 4) show that the first two axes explain $10.7 \%$ and $9.2 \%$, respectively, of the total inertia of the data table. Only the most contributing taxa (invasive and/or indigeneous taxa of the river macrofauna according to our expertise) are represented on the factorial map.

The first axis $(X$-axis) discriminates the three sites spatially, indicating a fundamentally different community along the Rhône while the second axis ( $Y$-axis) shows a temporal evolution towards a more or less pronounced unified community in each site. The Upper Rhône appears as the site with the highest taxonomic diversity.

The flood of November 2002 and the heat wave of summer 2003 seem to have marked a turn in the invertebrate communities of the Lower and Middle Rhône. If the latter underwent rather 
Hydraulicity Rhône Bugey

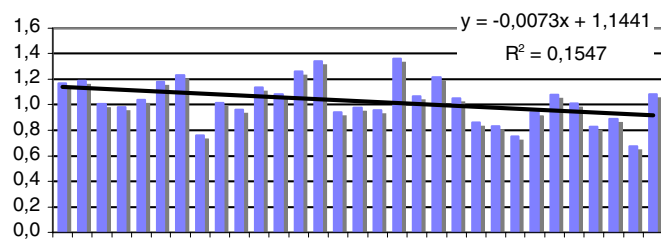

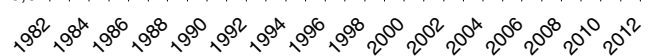

Hydraulicity Rhône St-Alban

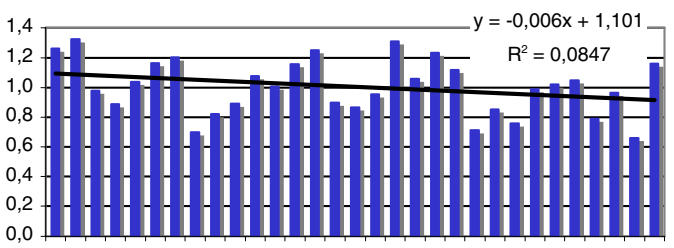

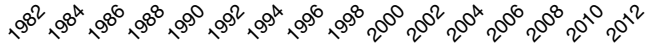

Hydraulicity Rhône Tricastin

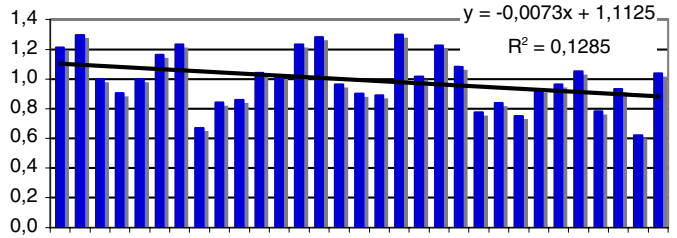

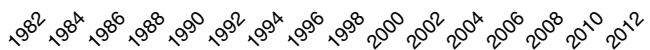

Temperature Rhône Bugey

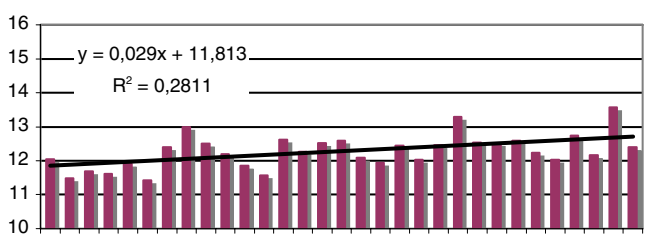

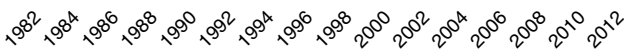

Temperature Rhône St-Alban

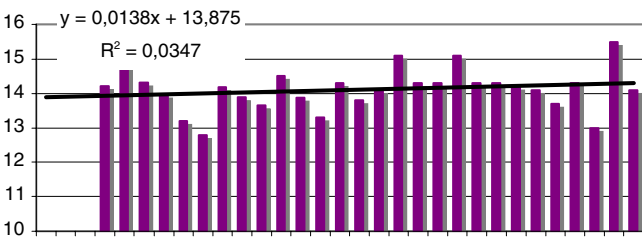

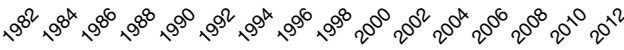

Temperature Rhône Tricastin

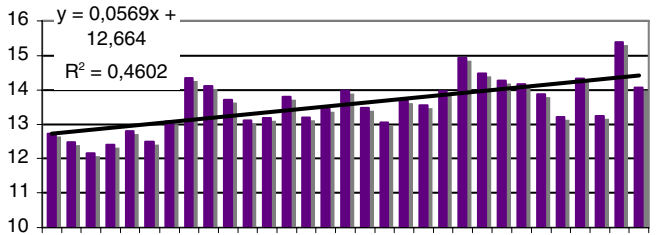

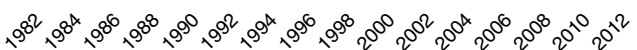

\section{Figure 3}

Changes in the hydro-climatic variables of the different sections vs. time, expressed as mean annual values. Data from EDF nuclear power plant environmental survey programmes for temperature $\left({ }^{\circ} \mathrm{C}\right)$ and from CNR gauging stations for discharge, expressed as hydraulicity coefficients (www.rdbrmc.com/ hydroreel2).

linear changes, a real break appeared in the Lower Rhône after 2002. The Upper Rhône also followed this trend although the changes were much less marked. This seems to have lead to a greater uniformity of communities along the river after 2003.

A more detailed analysis of taxon distribution showed the strong influence of recent alien species such as the crustaceans Jaera istri (Jaeist), Chelicorophium curvispinum (Checur) and Limnomysis benedeni (Limben, even in lower numbers), or the polychaete Hypania invalida (Hypinv), in the benthic assemblages of the Middle and Lower Rhône.

\section{> TRAIT-BASED APPROACH}

When the bio-ecological average profiles per stations of the Rhône River were established, four main traits showed a temporal effect in the Middle and Lower Rhône: the number of generations (i.e. number of reproductive cycles per year), the mode of reproduction, the respiration and the longitudinal distribution (corresponding to biological traits "number of reproductive cycles per year", "reproduction" and "respiration" and ecological one "longitudinal distribution" in Tachet et al.'s classification - see Appendices 2 and 3). In contrast, the Upper Rhône showed a high temporal stability of its bio-ecological profiles.

A demonstrative example is given with the biological trait "number of reproductive cycles per year" (Figure 5). This trait is stable in the Upper Rhône with a slight dominance of monovoltine species, especially during periods 2 and 3 . This temporal change in the two downstream sectors was confirmed by a Kruskal-Wallis test on each of the pairs sector $\mathrm{x}$ category of biological trait "number of reproductive cycles per year". Except for the category "> $>$ cycle 


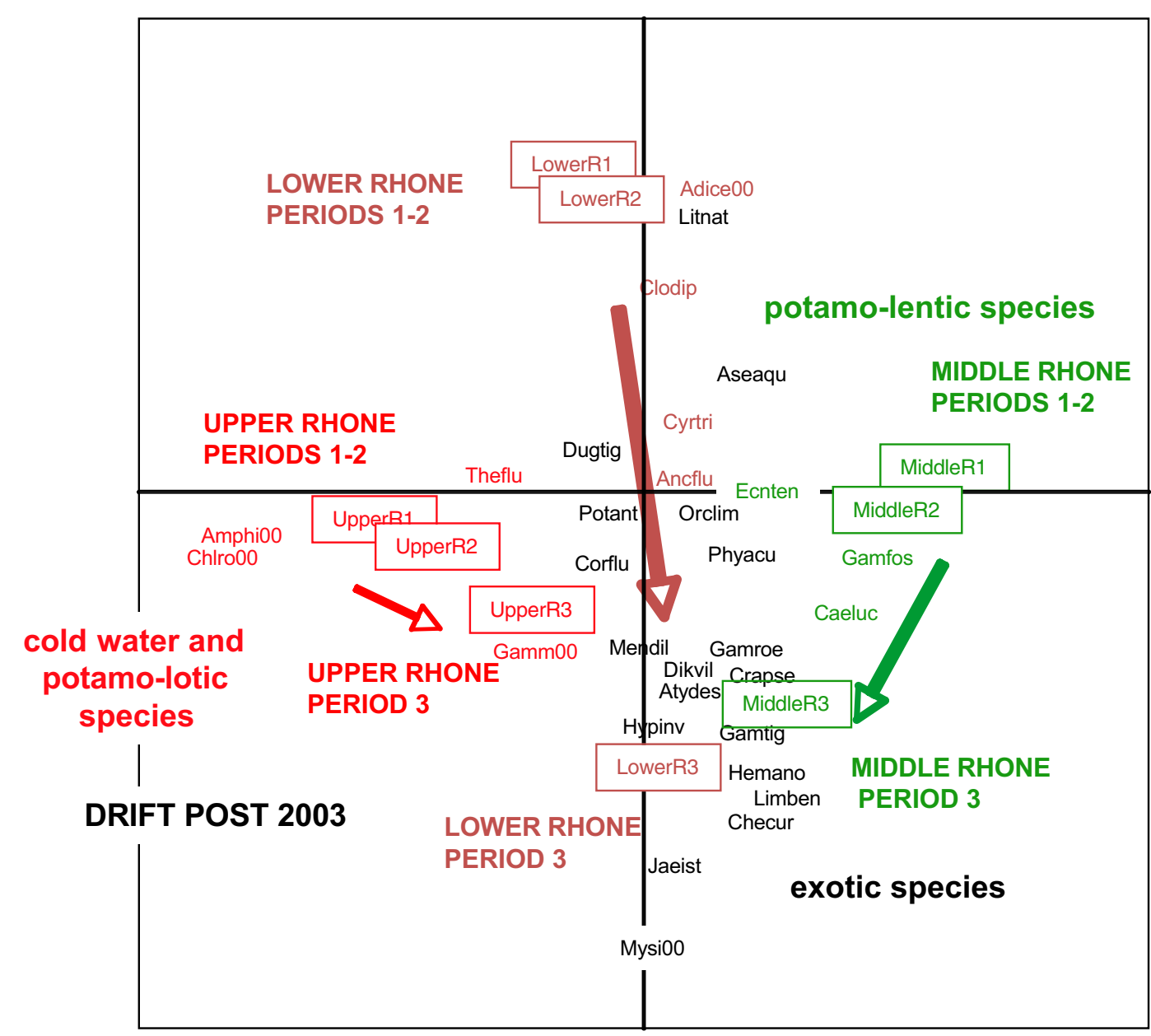

\section{Figure 4}

Changes in the macroinvertebrate communities of the Rhône River between 1985 and 2010, and projection of the most contributing species. Three sectors : Upper Rhône (Bugey) "UpperR", Middle Rhône (Saint-Alban) "MiddleR", Lower Rhône (Cruas-Tricastin) "LowerR". Three periods : 1979-1987 "1", 19882002 "2", 2003-2010 “3” (see Appendix 1 for species codes).

per year" in the Upper Rhône, this test is statistically significant for all pairs considered, very often with the critical value $p=0.01$ (Table I). In the Middle and Lower Rhône after the November 2002 flood and the 2003 heatwave it changed from a trait structure based on monovoltine species to a configuration in which the polyvoltine species dominated (a modality presumably influenced by the fact that warmer waters are favourable to alien species).

All the traits analysed show a true change of the community in the Middle and Lower Rhône after the November 2002 flood and the summer 2003 heatwave. Alien and Mediterranean species (and their specific characteristics) became dominant at the expense of more specialized native species. On the other hand, the Upper Rhône was characterized by the relative stability of traits over time.

The eigenvalues of the first two factorial axes in co-inertia analysis (Figure 6) provided 35\% and $25 \%$ of the total variance in the biological traits, respectively. The first axis opposed the Middle and Lower Rhône vs. the Upper Rhône, while the second axis rather reflected the temporal changes of the first two sectors.

The Upper Rhône remained fairly stable over time with a community mainly composed of individuals with short life cycles ( $<1$ year), aquatic larvae and/or pupae, reproducing by terrestrial clutches or cemented eggs, aerial dispersal and eggs as a resistance stage. Both downstream sectors are rather closely located on the first factorial plane during the first two periods (Figure 6). The corresponding communities comprised organisms with tegument 


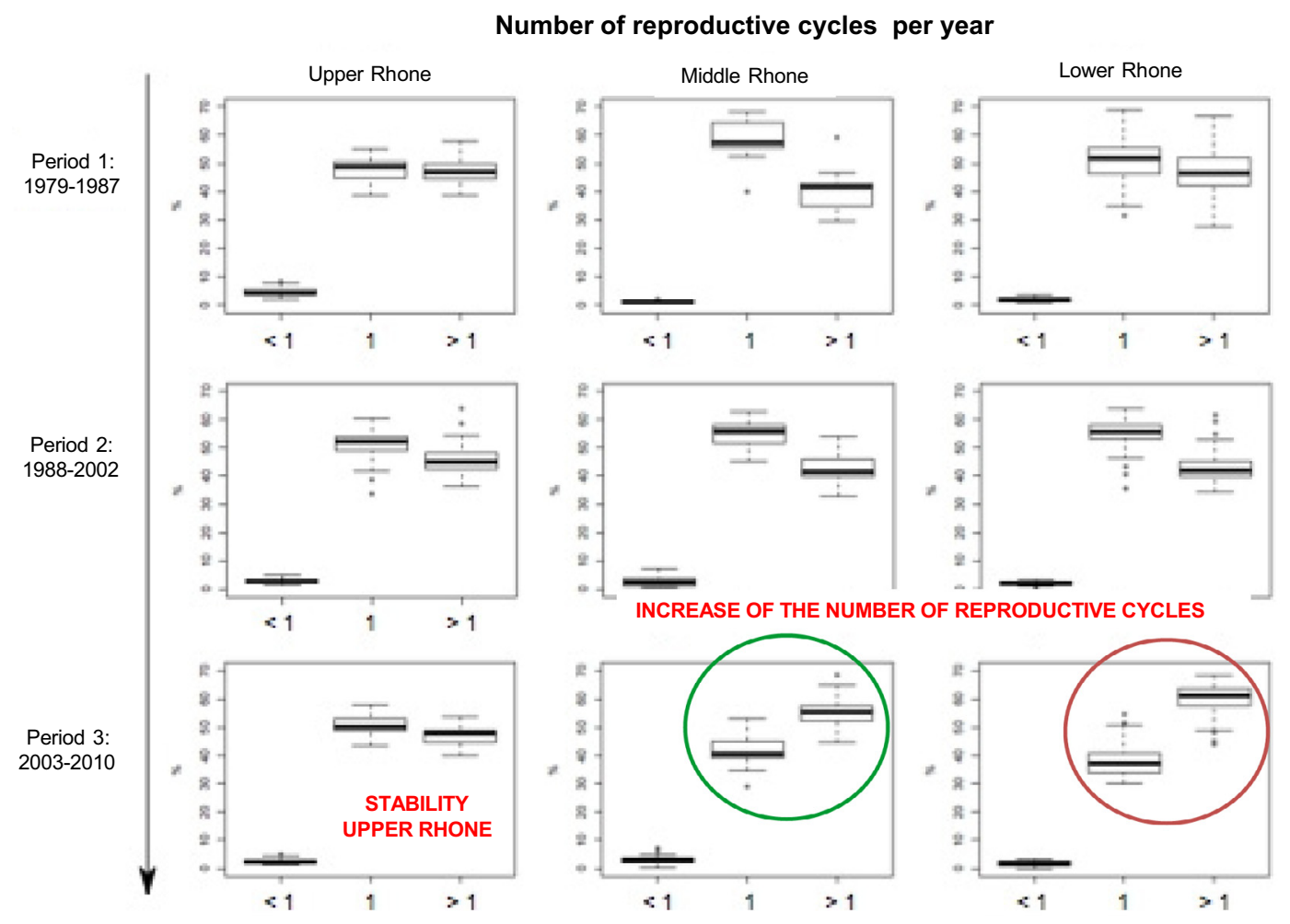

Figure 5

Functional approach: bio-ecological profiles. Example of average profiles of the biological trait "Potential number of reproductive cycles per year" per site.

\section{Table I}

Results of the Kruskall-Wallis test on the pairs sectors $x$ categories of biological trait "number of reproductive cycles per year". * : H critical value for $p(0.1 \%)=13.815-{ }^{* *}:$ H critical value for $p(1 \%)=9.21-$ *** : H critical value for $p(5 \%)=6.0$, NS : no significant value.

\begin{tabular}{|l|c|c|c|c|}
\hline \multirow{2}{*}{ Categorie } & Sector & $\begin{array}{c}\text { Upper } \\
\text { Rhône }\end{array}$ & $\begin{array}{c}\text { Midcle } \\
\text { Rhône }\end{array}$ & $\begin{array}{c}\text { Lower } \\
\text { Rhône }\end{array}$ \\
\hline \multirow{2}{*}{$<\mathbf{1}$ cycle/year } & observed value $H$ & 50.206 & 23.722 & 6.106 \\
\cline { 2 - 5 } & probability $P$ & $<0.0001^{*}$ & $<0.0001^{*}$ & $0.0472^{\star \star \star}$ \\
\hline \multirow{2}{*}{$=1$ cycle/year } & observed value $H$ & 16.014 & 40.470 & 84.178 \\
\cline { 2 - 5 } & probability $P$ & $0.0003^{*}$ & $<0.0001^{*}$ & $<0.0001^{*}$ \\
\hline \multirow{2}{*}{$>\mathbf{1}$ cycle/year } & observed value $H$ & 5.695 & 39.164 & 85.144 \\
\cline { 2 - 5 } & probability $P$ & $0.0580 \mathrm{NS}$ & $<0.0001^{*}$ & $<0.0001^{*}$ \\
\hline
\end{tabular}

respiration, asexual reproduction or cemented clutches, active aquatic dissemination, potential cells against desiccation or a diapause during their development. A shift in trait combinations appeared after 2003 in the Middle and especially the Lower Rhône communities, which were composed of polyvoltine, ovoviviparous species with gill respiration. All these attributes are frequently observed simultaneously in alien and/or Mediterranean species.

The eigenvalues of the co-inertia analysis (i.e. species abundances $x$ species ecological trait profiles) performed on the ecological traits (Figure 7) show that the first factorial axis represents $71 \%$ of the variance and the second one $10 \%$. The first axis opposes the Upper Rhône vs. the Middle and Lower Rhône, while the second axis rather reflects a different temporal drift in the three sectors over the period 2003-2010.

In the first two periods, the Upper Rhône invertebrate community was characterized by psychrophilic organisms, living in oligo- and mesotrophic freshwaters, preferentially in the piedmont section (altitude $<1000 \mathrm{~m}$ ) of rivers, on coarse mineral substrate, with moderate to fast current. The Lower and Middle Rhône communities included eurythermic species from 


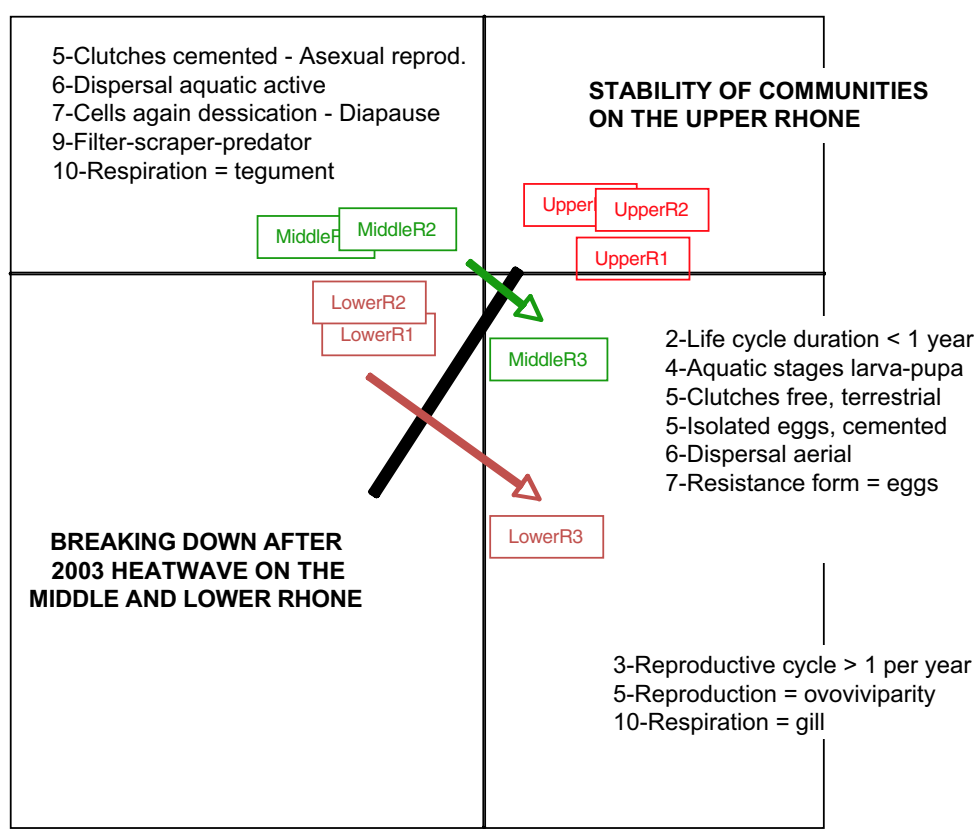

\section{Figure 6}

Co-inertia analysis of the biological traits. The numbers represent traits to which the different modalities belong (see Appendix 2 for trait and modality numbers).

downstream river sections with slow current (i.e. lowland rivers), ponds, marshes, and fine sediments or macrophytes as major bottom substrates.

The longitudinal Rhône River community gradient was underlined by clearly different attributes for the traits "altitude" (alpine vs. piedmont and lowlands), "saprobity" (xeno- and oligo- vs. mesosaprobic), "salinity" (freshwater vs. brackish water), "temperature" (psychrophilic vs. eurythermic), "trophic status" (oligo- and mesotrophic vs. eutrophic), "longitudinal distribution" (epi- and hypo-rhithron vs. metapotamon) and "transversal distribution" (river channel vs. side channel).

After 2003, the benthic communities of the three sectors became more ordinary with another set of bio/ecological attributes. The characteristics of the Upper and Middle Rhône communities became closer to those of the Lower Rhône as they had been before the 2003 heatwave, while the Lower Rhône community shifted to another type of community composed of thermophilic species of river downstream sections (e.g. metapotamon, and estuary).

\section{DISCUSSION}

\section{> TEMPORAL TAXONOMIC AND TRAIT-BASED SHIFT OF THE COMMUNITIES}

The gradual shift towards the homogenization of macroinvertebrate communities along the Rhône River noted in 2004 (Bady and Fruget, 2006) has increased during the more recent years. This trend was especially illustrated by the gradual change from a macrofauna of running and cold headwaters ( e.g. the stoneflies Chloroperla and Protonemura) in the Upper Rhône, to slow-flowing water and thermophilic species assemblages closer to those of downstream areas ( e.g. the caddisflies Hydroptilidae, the stoneflies Leuctridae in the Upper Rhône), with rather limnophilic taxa such as Hydrobiidae and Planorbidae molluscs (all sectors) and the appearance of various alien taxa (such as Corbicula, Dikerogammarus, Hypania in the three sectors and Jaera downstream from Lyon). These results have confirmed the observations made in previous studies on the Upper Rhône: mainly psychrophilic individuals were observed during the first two periods (Daufresne et al., 2003; Souchon et al., 2011). Floury et al. (2013) found the same trend in the Middle Loire River with a decrease 


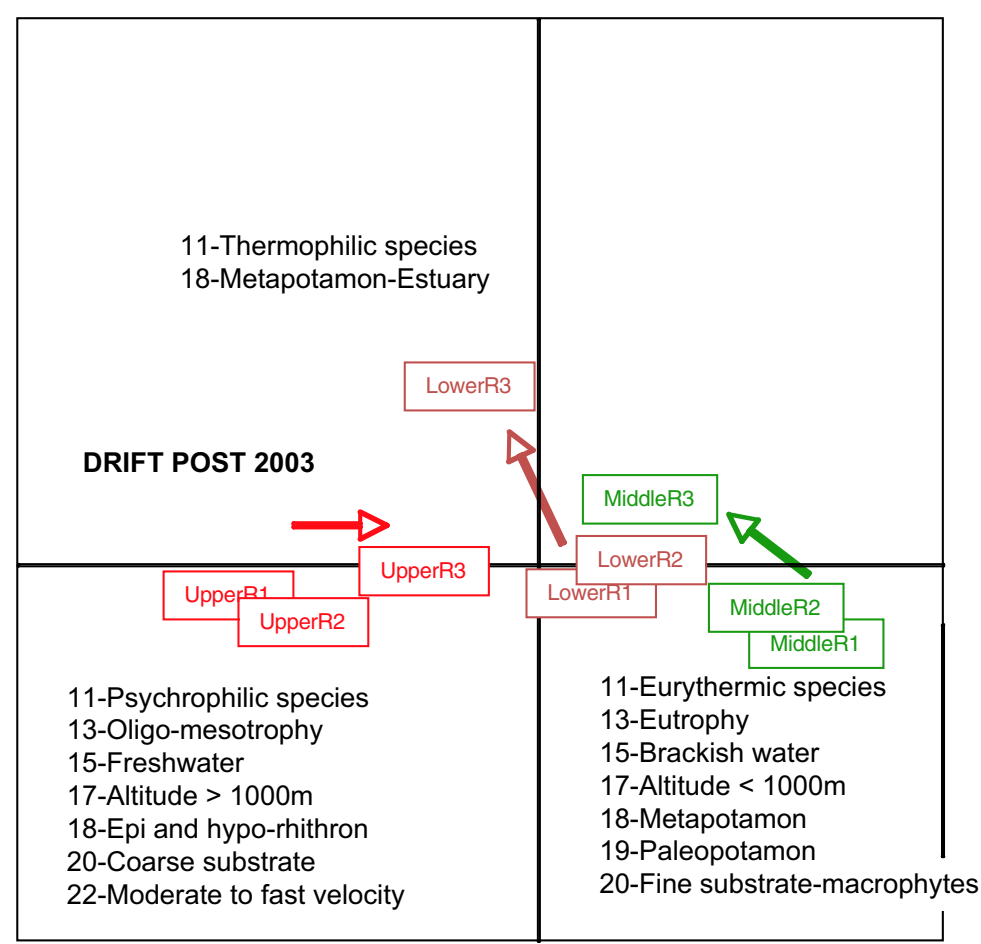

\section{Figure 7}

Co-inertia analysis of the ecological traits. The numbers represent traits to which the different modalities belong (see Appendix 3 for trait and modality numbers).

in rheophilic and psychrophilic taxa (e.g. Chloroperlidae) and an increase in limnophilic and thermophilic ones, which were also often invasive species (e.g. Mollusca Corbiculidae) during the last three decades.

Downstream from Lyon, the biological characteristics of invasive species and the affinity of invertebrate assemblages for Mediterranean environments increased following the floods of the early 2000 s and the heatwave in the summer of 2003. This influence is reflected in the dominant trait categories in invertebrate assemblages during the period 2000-2007, e.g. polyvoltine and ovoviviparous species with gill respiration. It indicates an increase in the thermal effect after 2003 and a water warming. This confirms the observation made by Khalanski et al. (2008) of a gradual increase in the average annual temperature along the Rhône River, with a greater shift in its downstream part.

Some traits reacted more specifically along the entire river and could thus serve as indicators (i.e. "metrics") of changing environmental conditions. These are:

- the duration of life cycles (less or more than one year) and the number of generations per year (mono- or polyvoltine species);

- the trophic status;

- temperature (psychrophily vs eurythermy), the longitudinal position on the river continuum and preferendum for substrate (coarse vs soft).

\section{$>$ DRIVING FACTORS}

Temperature is not the only driving factor which has influenced the French Rhône macrobenthic communities in the past 30 years. Even if they are more difficult to quantify, other driving forces must be considered: (i) the improvement of the physico-chemical quality (nutrients and dissolved oxygen) during the 1980s and early 1990s due to more efficient treatments and efforts to reduce urban wastes (Carrel, 2005), (ii) changes in river dynamics and sediment transport of the Upper Rhône with the gradual commissioning of all the CNR dams during 
the 1980s, and (iii) the water management of the Upper Rhône and associated energy hydropeakings with their consequences on the regime of the river. Nevertheless the thermal changes seem to be the main drinving factor, with hydrology (during the whole period) and main flood events (more specifically). These were in fact the most common causes of the spread of new taxa while temperature promoted their sustainable settlement (Fruget, 2003). These parallel and similar changes in communities subjected to different environmental conditions (e.g. free-flowing Rhône at Bugey vs artificial diversion canal at Tricastin) emphasize the dominant influence of climate change. These observations are in accordance with those made by Daufresne (2008) and Daufresne and Boët (2007) on the fish communities of various French large rivers (Seine, Loire, Rhône) and their significantly changing composition during the last decades.

Finally, this study once again emphasizes the importance of long-term monitoring for the study of biological communities on one hand, in the global warming context on the other hand.

\section{> PERSPECTIVES}

Ecological perspectives are difficult to establish. In a multiple stressor context, competition between native species and/or invasive ones acts in addition to anthropogenic effects (mostly on discharge and temperature). However, if the flow of invaders does not appear continuous but based on specific events (especially hydro-climatic events), one can legitimately believe that this drift will continue in the future.

Indeed, since the arrivals of Atyaephyra desmarestii and Gammarus roeseli in the mid-19th century, Devin et al. (2005) identified a total of 43 non-native species of invertebrates in French water courses. Thus, Bij de Vaate et al. (2002) identified fifteen Ponto-Caspian species which have penetrated the Rhine Basin. Ten of these are present in the Rhône Basin. This suggests that among species not yet present in the Rhône River, some of them will arrive during the next years, such as crustaceans Dikerogammarus bispinosus and Dikerogammarus haemobaphes, Echinogammarus ischnus and Echinogammarus trichiatus. The common feature of these different species is that they are mainly predators or filter-feeders, thermophilic and euryecic species, i.e. functional competitors according to the environmental changes of river characteristics.

The planarian Dendrocoelum romanodanubiale which is very common in the Moselle River, the bivalves Dreissena bugensis and Sinanodonta woodiana (already present in the Rhône basin according Mouthon, 2008) and the Asian tiger mosquito, Aedes albopictus (already present in southern France and now migrating up the Rhône valley) could also colonize the Rhône River in the coming years (J.N. Beisel, pers. comm.).

\section{ACKNOWLEDGEMENTS}

This work was supported by Electricité de France (EDF) in the framework of the research programme called "Étude Thermique Rhône Phase 4" (ETRP4). Financial support was also provided by the French Water Agency Rhône Méditerrannée \& Corse and the Council of Europe.

Data were taken from monitoring programmes carried out each year in the vicinity of EDF nuclear plants located along the Rhône River.

Many thanks to two anonymous reviewers whose comments and suggestions have greatly improved the early version of the draft, and to Professor Eric Pattee for english corrections. 
Appendix 1. Species codes.

\begin{tabular}{|l|c|c|}
\hline Code & Taxa & Group \\
\hline Adice00 & Adicella & Trichoptera \\
\hline Amphi00 & Amphinemura & Plecoptera \\
\hline Ancflu & Ancylus fluviatilis & Mollusc \\
\hline Aseaqu & Asellus aquaticus & Crustacea \\
\hline Atydes & Atyaephyra desmarestii & Crustacea \\
\hline Caeluc & Caenis luctuosa & Ephemeroptera \\
\hline Checur & Chelicorophium curvispinum & Crustacea \\
\hline Chloro00 & Chloroperla & Ephemeroptera \\
\hline Clodip & Cloeon dipterum & Ephemeroptera \\
\hline Corflu & Corbicula fluminea & Mollusc \\
\hline Crapse & Crangonyx pseudogracilis & Crustacea \\
\hline Cyrtri & Cyrnus trimaculatus & Trichoptera \\
\hline Dikvil & Dikerogammarus villosus & Crustacea \\
\hline Dugtig & Dugesia tigrina & Turbellaria \\
\hline Ecnten & Ecnomus tenellus & Trichoptera \\
\hline Gamfos & Gammarus fossarum & Crustacea \\
\hline Gamm00 & Gammarus & Crustacea \\
\hline Gamroe & Gammarus roeseli & Crustacea \\
\hline Gamtig & Gammarus tigrinus & Crustacea \\
\hline Hemano & Hemimysis anomala & Crustacea \\
\hline Hypinv & Hypania invalida & Polychaeta \\
\hline Jaeist & Jaera istri & Crustacea \\
\hline Limben & Limnomysis benedeni & Crustacea \\
\hline Litnat & Lithoglyphus naticoides & Mollusc \\
\hline Mendil & Menetus dilatatus & Mollusc \\
\hline Mysi00 & Mysidae & Crustacea \\
\hline Orclim & Orconectes limosus & Crustacea \\
\hline Phyacu & Physa acuta & Mollusc \\
\hline Theflu & Theodoxus fluviatilis & Mollusc \\
\hline & & \\
\hline
\end{tabular}

In italic alien species.

Appendix 2. List of biological traits and modalities of the aquatic macroinvertebrates used in this study (numbers from Tachet et al., 2000). Numbers were used as labels in Figure 6.

\begin{tabular}{|c|c|c|c|}
\hline No. & Traits & No. & Modalities \\
\hline \multirow[t]{7}{*}{1} & Maximum size & 1 & $\leqslant 0.25 \mathrm{~cm}$ \\
\hline & & 2 & $>0.25-0.5 \mathrm{~cm}$ \\
\hline & & 3 & $>0.5-1 \mathrm{~cm}$ \\
\hline & & 4 & $>1-2 \mathrm{~cm}$ \\
\hline & & 5 & $>2-4 \mathrm{~cm}$ \\
\hline & & 6 & $>4-8 \mathrm{~cm}$ \\
\hline & & 7 & $>8 \mathrm{~cm}$ \\
\hline \multirow[t]{2}{*}{2} & Life cycle duration & 1 & $\leqslant 1$ year \\
\hline & & 2 & $>1$ year \\
\hline \multirow[t]{3}{*}{3} & Potential number & 1 & $<1$ \\
\hline & of reproductive cycles & 2 & 1 \\
\hline & per year & 3 & $>1$ \\
\hline \multirow[t]{4}{*}{4} & Aquatic stages & 1 & egg \\
\hline & & 2 & larva \\
\hline & & 3 & pupa \\
\hline & & 4 & adult \\
\hline \multirow[t]{6}{*}{5} & Reproduction & 1 & ovoviviparity \\
\hline & & 2 & isolated eggs, free \\
\hline & & 3 & isolated eggs, cemented \\
\hline & & 4 & clutches, cemented or fixed 5 clutches, free \\
\hline & & 6 & eggs or clutches, in vegetation (endophytic) \\
\hline & & 7 & $\begin{array}{c}\text { clutches, terrestrial } \\
\text { asexual renroduction }\end{array}$ \\
\hline & & & asexuar repiouluctivir \\
\hline
\end{tabular}


Appendix 2. Continued.

\begin{tabular}{|c|c|c|c|}
\hline No. & Traits & No. & Modalities \\
\hline \multirow[t]{4}{*}{6} & Dispersal & 1 & aquatic passive \\
\hline & & 2 & aquatic active \\
\hline & & 3 & aerial passive \\
\hline & & 4 & aerial active \\
\hline \multirow[t]{5}{*}{7} & Resistance form & 1 & eggs, statoblats, gemmules \\
\hline & & 2 & cocoons \\
\hline & & 3 & cells against desiccation \\
\hline & & 4 & diapause or dormancy \\
\hline & & 5 & none \\
\hline \multirow[t]{9}{*}{8} & Food & 1 & Fine sediment + microorganisms \\
\hline & & 2 & detritus $<1 \mathrm{~mm}$ \\
\hline & & 3 & plant detritus $\geqslant 1 \mathrm{~mm}$ \\
\hline & & 4 & living microphytes \\
\hline & & 5 & living macrophytes \\
\hline & & 6 & dead animals $\geqslant 1 \mathrm{~mm}$ \\
\hline & & 7 & living microinvertebrates \\
\hline & & 8 & living macroinvertebrates \\
\hline & & 9 & vertebrates \\
\hline \multirow[t]{8}{*}{9} & Feeding habits & 1 & absorber \\
\hline & & 2 & deposit feeder \\
\hline & & 3 & shredder \\
\hline & & 4 & scraper \\
\hline & & 5 & filter-feeder \\
\hline & & 6 & piercer (plants or animals) \\
\hline & & 7 & predator (carver/engulfer/wallower) \\
\hline & & 8 & parasite, parasitoïd \\
\hline \multirow[t]{5}{*}{10} & Respiration & 1 & tegument \\
\hline & & 2 & gill \\
\hline & & 3 & plastron \\
\hline & & 4 & spiracle (aerial) \\
\hline & & 5 & hydrostatic vesicle \\
\hline \multirow[t]{8}{*}{21} & Locomotion and & 1 & flier \\
\hline & substrate relation & 2 & surface swimmer \\
\hline & & 3 & swimmer \\
\hline & & 4 & crawler \\
\hline & & 5 & burrower (epibenthic) \\
\hline & & 6 & interstitial (endobenthic) \\
\hline & & 7 & temporarily attached \\
\hline & & 8 & permanently attached \\
\hline
\end{tabular}

Appendix 3. List of ecological traits and modalities of the aquatic macroinvertebrates used in this study (numbers from Tachet et al., 2000). Numbers were used as labels in Figure 7.

\begin{tabular}{|c|c|c|c|}
\hline No. & Traits & No. & Modalities \\
\hline $\mathbf{1 1}$ & Temperature & 1 & cold $\left(<15^{\circ} \mathrm{C}\right)$ \\
& preferences & 2 & warm $\left(>15^{\circ} \mathrm{C}\right)$ \\
& & 3 & eurythermic \\
$\mathbf{1 2}$ & $\mathrm{pH}$ & 1 & $\leqslant 4$ \\
& preferences & 2 & $>4-4.5$ \\
& & 3 & $>4.5-5$ \\
& & 4 & $>5-5.5$ \\
& & 5 & $>5.5-6$ \\
& & 6 & $>6$ \\
\hline
\end{tabular}


Appendix 3. Continued.

\begin{tabular}{|c|c|c|c|}
\hline No & Traits & No & Modalities \\
\hline \multirow[t]{3}{*}{13} & Trophic status & 1 & oligotrophic \\
\hline & preferences & 2 & mesotrophic \\
\hline & & 3 & eutrophic \\
\hline \multirow[t]{5}{*}{14} & Saprobity & 1 & xenosaprobic \\
\hline & (according Sladecek, 1973) & 2 & oligosaprobic \\
\hline & & 3 & beta-mesosaprobic \\
\hline & & 4 & alpha-mesosaprobic \\
\hline & & 5 & polysaprobic \\
\hline \multirow[t]{2}{*}{15} & Salinity & 1 & freshwater \\
\hline & preferences & 2 & brackish water \\
\hline \multirow[t]{4}{*}{16} & Biogeographic region & 1 & 2: Pyrenees \\
\hline & (accoining mines, liso) & 3 & 8: Vosges, Jura, Massif Central \\
\hline & & 4 & 13a: lowlands (oceanic) \\
\hline & & 5 & 13b : lowlands (mediterranean) \\
\hline \multirow[t]{3}{*}{17} & Altitude & 1 & lowlands $(<1000 \mathrm{~m})$ \\
\hline & & 2 & mountain level (1000-2000 m) \\
\hline & & 3 & alpine level (> 2000 m) \\
\hline \multirow[t]{7}{*}{18} & $\begin{array}{l}\text { Longitudinal distribution } \\
\text { (according llies \& }\end{array}$ & $\begin{array}{l}1 \\
2\end{array}$ & $\begin{array}{c}\text { crenon } \\
\text { epirithron }\end{array}$ \\
\hline & Botosaneanu, 1963) & 3 & metarhithron \\
\hline & & 4 & hyporhithron \\
\hline & & 5 & epipotamon \\
\hline & & 6 & metapotamon \\
\hline & & 7 & 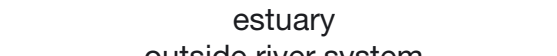 \\
\hline & Transyersal distribution & $\begin{array}{l}8 \\
1\end{array}$ & $\begin{array}{l}\text { outside river system } \\
\text { river channel }\end{array}$ \\
\hline \multirow{6}{*}{19} & 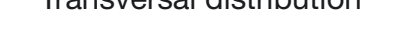 & 2 & banks, connected side-arms \\
\hline & & 3 & ponds, pools, disconnected side-arms \\
\hline & & 4 & marshes, peat bogs \\
\hline & & 5 & temporary waters \\
\hline & & 6 & lakes \\
\hline & & 7 & $\begin{array}{l}\text { groundwaters } \\
\end{array}$ \\
\hline \multirow{8}{*}{20} & $\begin{array}{l}\text { Substrate } \\
\text { preferences }\end{array}$ & $\begin{array}{l}1 \\
2\end{array}$ & $\begin{array}{c}\text { flags/boulders/cobbles/pebbles } \\
\text { gravel }\end{array}$ \\
\hline & & 3 & sand \\
\hline & & 4 & silt \\
\hline & & 5 & macrophytes \\
\hline & & 6 & microphytes \\
\hline & & 7 & twigs/roots \\
\hline & & 8 & organic detritus/litter \\
\hline & & 9 & mud \\
\hline \multirow[t]{5}{*}{22} & Current velocity & 1 & null \\
\hline & preferences & 2 & slow $\left(<25 \mathrm{~cm} \cdot \mathrm{s}^{-1}\right)$ \\
\hline & & 3 & moderate $\left(25-50 \mathrm{~cm} \cdot \mathrm{s}^{-1}\right)$ \\
\hline & & 4 & fast $\left(>50 \mathrm{~cm} \cdot \mathrm{s}^{-1}\right)$ \\
\hline & & 5 & \\
\hline
\end{tabular}

\section{REFERENCES}

Bady P. and Fruget J.F., 2006. Étude thermique globale du Rhône. Phase 3. Influence de la variabilité hydroclimatique 1985-2004 sur les peuplements de macroinvertébrés. Report Aralep to EDF DTG, $28 \mathrm{p}$.

Bij de Vaate A., Jazdzewski K., Ketelaars H.A.M., Gollasch S. and Van der Velde G., 2002. Geographical patterns in range extension of Ponto-caspian macroinvertebrate species in Europe. Can. J. Fish. Aquat. Sci., 59, 1159-1174.

Bonada N., Dolédec S. and Statzner B., 2007. Taxonomic and biological trait differences of stream macroinvertebrate communities between Mediterranean and temperate regions: implications for future climatic scenarios. Global Change Biol., 13, 1658-1671. 
Carrel G., 2005. Caractérisation physico-chimique des eaux du Rhône. Évolution des paramètres classiques au cours de la période 1985 - 2004. Report Cemagref Aix-en-Provence to EDF DTG, 16 p.

Carrel G., Desaint B., Fruget J.F., Khalanski M., Olivier J.M., Poirel A. and Souchon Y., 2006. Étude thermique globale du Rhône - Phase 3. Report Aralep, Université Lyon, Cemagref, EDF.

Charvet S., Statzner B., Usseglio-Polatera P., and Dumont B., 2000. Traits of benthic macroinvertebrates in semi-natural French streams: an initial application to biomonitoring in Europe. Freshwater Biol., 43, 277-296.

Dai A., Qian T., Trenberth K.E. and Milliman J.D., 2009. Changes in continental freshwater discharge from 1948-2004. J. Climate, 22, 2773-2791.

Daufresne M., 2008. Impacts des changements climatiques et non climatiques sur les communautés piscicoles de grands fleuves français. Hydroécologie Appliquée 16, 109-134.

Daufresne M. and Boët P., 2007. Climate change impacts on structure and diversity of fish communities in rivers. Global Change Biol., 13, 2467-2478.

Daufresne M., Roger M.C., Capra H. and Lamouroux N., 2003. Long-term changes within the invertebrate and fish communities of the Upper Rhône River: effects of climatic factors. Global Change Biol., 10, 124-140.

Daufresne M., Bady P. and Fruget J.F., 2007. Impacts of global changes and extreme hydroclimatic events on macroinvertebrate community structures in the French Rhône River. Oecologia, 151, 544-559.

Dessaix J., Fruget J.F., Olivier J.M. and Beffy J.L., 1995. Changes of the macroinvertebrate communities in the dammed and by-passed sections of the French Upper Rhône after its regulation. Regulated Rivers, 10, 265-279.

Devin S., Bollache L., Noël P.Y. and Beisel J.N., 2005. Patterns of biological invasions in French freshwater systems by non-indigenous macroinvertebrates. Hydrobiologia, 551, 137-146.

Dolédec S. and D. Chessel 1994. Co-inertia analysis: an alternative method for studying speciesenvironment relationships. Freshwater Biol., 31, 277-294.

Ducrot V., Usseglio-Polatera P., Péry A., Mouthon J., Laffont M., Roger M.-C., Garric J. and Férard J.-F., 2005. Using aquatic macroinvertebrate species traits to build test batteries for sediment toxicity assessment: accounting for the diversity of potential biological responses to toxicants. Environ. Toxicol. Chem., 24, 2306-2315.

Dynesius M. \& Nilsson C., 1994. Fragmentation and flow regulation of river systems in the northern third of the world. Science, 266, 753-762.

Floury M., Usseglio-Polatera P., Ferreol M., Delattre C. and Souchon Y., 2013. Global climate change in large European rivers : long-term effects on macroinvertebrate communities and potential local confounding factors. Global Change Biol., 19, 1085-1099.

Fruget J.F., 1992. Ecology of the Lower Rhône following 200 years of human influence: a review. Regulated Rivers, 7, 233-246.

Fruget J.F., 2003. Changements environnementaux, dérives écologiques et perspectives de restauration du Rhône Français: bilan de 200 ans d'influences anthropiques. VertigO, 4, 1-17.

Giuntoli I., Maugis P. and Renard B., 2012. Évolutions observées dans les dénits des rivières en France. Sélection d'un réseau de référence et analyse de l'évolution temporelle des régimes des 40 dernières années. Collection « Comprendre pour agir », Onema, Paris, 8 p.

Hendricks F., 2001. Impact hydrologique d'un changement climatique sur le bassin du Rhône. Hydroécologie Appliquée, 13, 77-100.

IPCC 2013. Climate Change 2013: The Physical Science Basis. Summary for Policymakers. Contribution of Working Group I to the Fifth Assessment Report of the Intergovernmental Panel on Climate Change. Cambridge University Press, Cambridge, UK, 29 p.

Khalaf G. and Tachet H., 1980. Colonization of artificial substrata by macroinvertebrates in a stream and variations accordind to stone size. Freshwater Biol. 10, 475-482.

Khalanski M., Carrel G., Desaint B., Fruget J.F., Olivier J.M., Poirel A. and Souchon Y., 2008. Etude thermique globale du Rhône - Impacts hydrobiologiques des échauffements cumulés. Hydroécologie Appliquée, 16, 53-108.

Lecerf A., Usseglio-Polatera P, Charcosset J.-Y., Lambrigot D., Bracht B. and Chauvet E., 2006. Assessing functional integrity of eutrophicated streams using direct and indirect approaches: litter breakdown versus macrobenthic assemblage taxonomic and trait structure. Archiv für Hydrobiologie, 165, 105-126. 
Mouthon J., 2008. Découverte de Sinanodonta woodiana (Lea, 1834) (Bivalvia: Unionacea) dans un réservoir eutrophe: le Grand Large en amont de Lyon (Rhône, France). MalaCo, 5, 241-243.

Petts G.E., Moller H. and Roux A.L. (eds.), 1989. Historical change of large alluvial rivers: Western Europe. J. Wiley and Sons, Chichester, 355 p.

Piscart C., Lecerf A., Usseglio-Polatera P., Moreteau J.C. and Beisel J.N., 2005. Biodiversity patterns along a salinity gradient: the case of net-spinning caddisflies. Biodiversity \& Conservation, 14, 2235-2249.

Piscart C., Usseglio-Polatera P., Moreteau J.C. and Beisel J.N., 2006. The role of salinity in the selection of biological traits of freshwater invertebrates. Archiv für Hydrobiologie, 166, 185-198.

Souchon Y., Roger M.C., Villeneuve B. and Piffady J., 2011. Rhône amont. CNPE Bugey. Tendances temporelles de l'hydrologie, de la température et des communautés biologiques de macroinvertébrés et de poisons au cours des trente dernières années (1980-2009). Report CEMAGREF Lyon to EDF $R \& D, 56 \mathrm{p}$.

Southwood T.R.E., 1977. Habitat, the templet for ecological strategies? J. Animal Ecol., 46, 337-365.

Stahl K., Hisdal H., Hannaford J., Tallaksen L.M., Van Lanen H.J., Sauquet E., Demuth S., Fendekova M. and Jodar J., 2010. Streamflow trends in Europe: evidence from a dataset of near-natiral catchments. Hydrol. Earth Syst. Sci., 14, 2367-2382.

Statzner B. and Bêche L., 2010. Can biological invertebrate traits resolve effects of multiple stressors on running water ecosystems? Freshwater Biol., 55, 80-119.

Statzner B., Hoppenhaus K., Arens M.-F. and Richoux P., 1997. Reproductive traits, habitat use and templet theory: a synthesis of world-wide data on aquatic insects. Freshwater Biol., 38, 109-135.

Statzner B., Dolédec S. and Hugueny B., 2004. Biological trait composition of European stream invertebrate communities: assessing the effects of various trait filter types. Ecography, 27, 470-488.

Statzner B., Bady P., Dolédec S. and Schöll F., 2005. Invertebrate traits for the biomonitoring of large European rivers: an initial assessment of trait patterns in least impacted river reaches. Freshwater Biol., 50, 2136-2161.

Statzner B., Bonada N. and Doledec S., 2008. Biological attributes discriminating invasive from native European stream macroinvertebrates. Biological Invasions, 10, 517-530.

Stenseth N.C., Mysterud A., Ottersen G., Hurrell J.W., Chan K.S. and Lima M., 2002. Ecological effects of climate fluctuations. Science, 297, 1292-1296.

Tachet H., Richoux P., Bournaud M. and Usseglio-Polatera P., 2000. Invertébrés d'eau douce, Systématique, biologie, écologie, 4th edition. CNRS Eds., Paris, 587 p.

Tockner K., Pusch M., Borchardt D. and Lorang M.S., 2010. Multiple stressors in coupled river-floodplain ecosystems. Freshwater Biol., 55, 135-151.

Townsend C.R. and Hildrew A.G., 1994. Species traits in relation to a habitat templet for rivers systems. Freshwater Biol., 31, 265-275.

Townsend C.R., Dolédec, S. and Scarsbrook M., 1997. Species traits in relation to temporal and spatial heterogeneity in streams: a test of habitat templet theory. Freshwater Biol., 37, 367-387.

Usseglio-Polatera P., Bournaud M., Richoux P. and Tachet H., 2000. Biological and ecological traits of benthic freshwater macroinvertebrates: relationship and definition of groups with similar traits. Freshwater Biol. , 43, 175-205.

Cite this article as: J.-F. Fruget, C. Jézéquel, G. Archambaud, J. Dessaix and M.-C. Roger, 2015. Long-term effects of global and local changes on benthic macroinvertebrate communities in multistressed large rivers: the example of the Rhône River during the last 30 years. Knowl. Manag. Aquat. Ecosyst., 416, 29. 